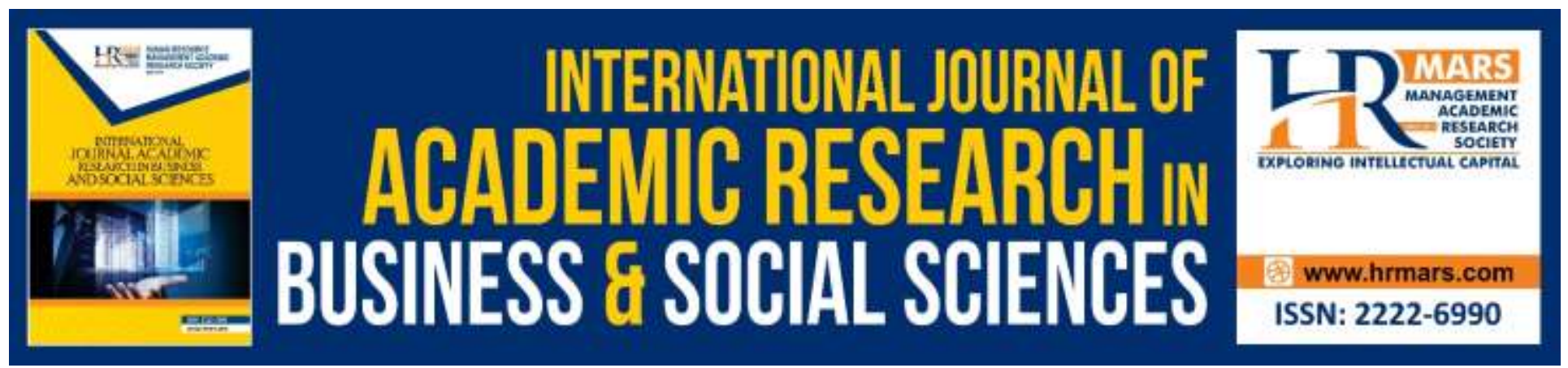

\title{
Readers' Comprehension of the Translation of Words with Multiple Meanings in the Tafsir Pimpinan Ar-Rahman
}

\author{
Idris Mansor, Kasyfullah Abd Kadir
}

To Link this Article: http://dx.doi.org/10.6007/IJARBSS/v8-i7/4320

DOI: $10.6007 /$ IJARBSS/v8-i7/4320

Received: 23 May 2018, Revised: 23 June 2018, Accepted: 30 June 2018

Published Online: 08 July 2018

In-Text Citation: (Mansor \& Kadir, 2018)

To Cite this Article: Mansor, I., \& Kadir, K. A. (2018). Readers' Comprehension of the Translation of Words with Multiple Meanings in the Tafsir Pimpinan Ar-Rahman. International Journal of Academic Research in

Business and Social Sciences, 8(7), 8-22.

\section{Copyright: () 2018 The Author(s)}

Published by Human Resource Management Academic Research Society (www.hrmars.com)

This article is published under the Creative Commons Attribution (CC BY 4.0) license. Anyone may reproduce, distribute, translate and create derivative works of this article (for both commercial and non-commercial purposes), subject to full attribution to the original publication and authors. The full terms of this license may be seen at: http://creativecommons.org/licences/by/4.0/legalcode

Vol. 8 , No. 7, July 2018, Pg. $8-22$

Full Terms \& Conditions of access and use can be found at http://hrmars.com/index.php/pages/detail/publication-ethics 


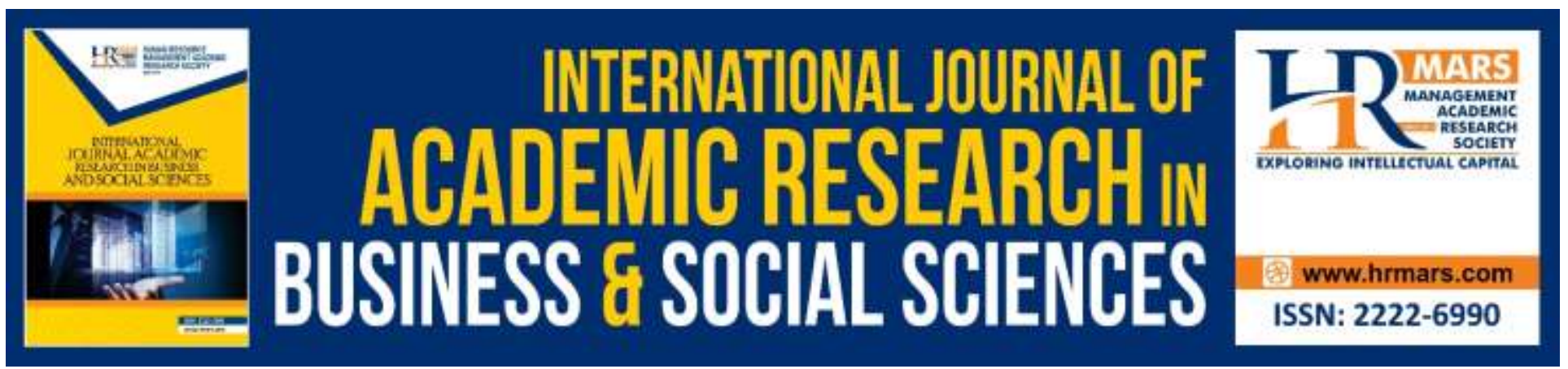

\title{
Readers' Comprehension of the Translation of Words with Multiple Meanings in the Tafsir Pimpinan Ar-Rahman
}

\author{
Idris Mansor
}

School of Humanities, Universiti Sains Malaysia, 11800 USM Pulau Pinang, Malaysia.

Email: idrismansor@usm.my

Kasyfullah Abd Kadir

Centre for Fundamental and Liberal Education, Universiti Malaysia Terengganu, 21030 Kuala

Terengganu, Terengganu, Malaysia.

Email: kasyfullah.kadir@umt.edu.my

\begin{abstract}
Al-Qur'an that was revealed in Arabic also contains words with elements of mushtarak or words with more than one meaning. In this case, the translator needs to carefully select the most appropriate equivalence among other equivalences available in the target language. Inaccuracy in selecting the most appropriate equivalence can disrupt the comprehension level of the target readers. This study aims to assess the level of comprehension amongst readers of the Malay translated text of al-Qur'an by Abdullah Basmeih entitled Tafsir Pimpinan Ar-Rahman Kepada Pengertian Al-Qur'an, specifically towards the translation of mushtaraks and their verses. A survey was conducted and questionnaires were distributed to 300 respondents. The data were analysed using a simple percentage calculation. In addition, interviews with three respondents were carried out to support the findings of the survey. Overall, the study finds that majority of the respondents are able to understand the translated words of mushtarak and their relevant verses. However, the findings also reveal the difficulties faced by some respondents in understanding the translation provided by the translator due to the ambiguous sentences and awkward equivalences. This situation therefore provides more room to present alQur'an translators for revisions and improvements of the translation done by Abdullah Basmeih.

Keywords: Al-Qur'an Translation, Multiple Meanings, Comprehension, Tafsir Pimpinan Ar-Rahman, Malay language.

\section{Introduction}

Ambiguity is a common phenomenon in any language. According to Larson (1984), ambiguity occurs when a word has more than one meaning and there is no context to help determine the correct meaning. However, ambiguity in a text does not necessarily indicate that the text is weak. There are
\end{abstract}


INTERNATIONAL JOURNAL OF ACADEMIC RESEARCH IN BUSINESS AND SOCIAL SCIENCES

Vol. 8, No. 7, July 2018, E-ISSN: 2222-6990 @ 2018 HRMARS

times when the opposite could be true as ambiguity could also mean that the text is of high quality. Newmark (1998) suggests that "a linguistic ambiguity may enrich a text and both meanings may be intended" because writers may employ ambiguity intentionally for creativity purposes as well as to enhance the quality of their texts.

Al-Qur'an as a sacred text for the Muslims also contains ambiguity. It is ambiguity, in fact, that prompts discussions among scholars about the translatability ${ }^{1}$ of al-Qur'an. Abdul-Raof (2001) is one such scholar who has conducted a comprehensive discussion on issues concerning the translatability of al-Qur'an and ambiguity is one of the issues covered in his discussion.

According to Hudson (2000), among the main factors which cause ambiguity in a language is the existence of words that have more than one possible meaning. This concept is known as mushtarak in the Arabic linguistic studies. Mushtarak refers to words with two or more different meanings (Ibn Faris, 1997). This definition is similar to the concepts of homonyms and polysemy in the modern linguistic terms.

In linguistics, translation refers to the process of matching words from the source text with words that have equal meaning in the target language. As such, when translators encounter possible equivalents that have multiple meanings, they need to be doubly careful. This is to avoid confusion that may result from mistakes in determining the correct meaning as intended in the source text. One example is the translation of the word rijälan in the following verse:

[Surah al-Hajj: 27]

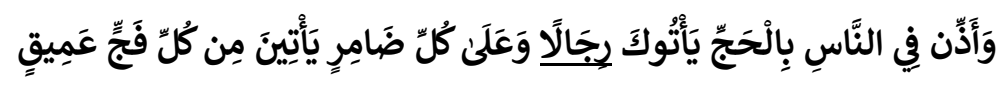

"Dan serukanlah umat manusia untuk mengerjakan ibadat Haji, nescaya mereka akan datang ke (rumah Tuhan) mu dengan berjalan kaki, dan dengan menunggang berjenis-jenis unta yang kurus yang datangnya dari berbagai jalan (dan ceruk rantau) yang jauh. (Basmeih, 2001: 22/27)

The word rijālan in this verse was translated by Nazwar Syamsu in 'Kamus al-Qur'an' as 'berlaki-laki'. Rijālan is an ambiguous word that has two possible meanings namely 'male' [lelaki in Malay] and 'to walk barefoot' [berjalan kaki in Malay]. Due to either confusion or misunderstanding of the Arabic word, he has produced an inaccurate translation which diverts from the original meaning in al-Qur'an (Fadzil 2007). (Note: the translation 'berlaki-laki' is a nonsensical word which seems to be a combination of both possible meanings 'lelaki' and 'berjalan kaki').

According to Dastjerdi \& Zamani (2009), mushtarak words often cause problems in the process of translation due to ambiguous meanings. Findings from their study have shown that translators can determine the meaning for mushtarak words in al-Qur'an by referring to the contextual clues, which in turn will allow them to find the correct translations for the ambiguous words.

Other than the problem of determining the correct equivalents, rigid translations may also cause problems for readers to understand the translations of al-Qur'an. Among the factors for this is the translation approach employed by the translators. Translators who rigidly follow the syntax and structure of the source text are likely to produce translations that readers of the target text may find

1 Translatability refers to the extent to which a word or phrase or a whole text can be translated from one language to another (Shuttleworth \& Cowie, 1997: 179). 
difficult to understand (Hanapi, 2009). In translation studies, this approach to translation is known as the literal translation approach.

To help readers understand the translations of al-Qur'an, Abdul-Raof (2001) proposed that translators use the explicitation procedure (Vinay \& Darbelnet, 1995; Idris Mansor, 2012) to translate the holy verses of al-Qur'an. Using this procedure, translators need to provide explanation whether in text or through footnote, or to choose specific equivalents available in the target source that have the same meaning as the words in al-Qur'an to solve the ambiguities including the mushtarak elements.

By focusing on the translation of al-Qur'an into Malay, it also involves words with multiple meanings which is mushtarak. This study therefore is conducted with the aim to study the level of comprehension and acceptance among the readers of the translation of Quranic mushtarak words into Malay. This study is significant since apart from identifying the level of comprehension among readers, improvements and revisions can be proposed should there be such a need.

For the purpose of this study, Tafsir Pimpinan Ar-Rahman Kepada Pengertian Al-Qur'an by Abdullah Basmeih is selected as it is the translation of al-Qur'an into Malay that is recognised by the government.

With this background in mind, this research is conducted with the aim to study the level of comprehension and acceptance among the readers of the translation of al-Qur'an into Malay, particularly concerning mushtarak words.

Tafsir Pimpinan Ar-Rahman Kepada Pengertian Al-Qur'an by Abdullah Basmeih is selected for the purpose of this study as it is the translation of al-Qur'an into Malay that is recognised by the government. This study is significant since apart from identifying the level of comprehension among readers, improvements and revisions can be proposed should there be such a need.

\section{Methodology}

This is a quantitative descriptive research. This study examines al-Qur'an as the source text and a translation of al-Qur'an into Malay as the target text. The selected target text is Tafsir Pimpinan alRahman Kepada Pengertian al-Quran (TPA) by Syeikh Abdullah Muhammad Basmeih, published by Dar al-Fikr, Kuala Lumpur with permission and under the regulation of the Department of Islamic Development Malaysia (JAKIM), and printed by Yayasan Islam Terengganu in 2001. This text is selected as it is the translation of al-Qur'an into Malay that is recognised by JAKIM, the government body responsible for regulating the publication of al-Qur'an and other Islamic publications. The text is a direct translation from Arabic into Malay.

The data for this research were collected through a survey. A survey questionnaire was developed based on the model of mushtarak in al-Qur'an proposed by al-Munajjid in his book Alishtirak al-lafdhi fi al-Qur'an al-karim; bayna an-nadhariyyah wa at-tatbiq. The survey questionnaire has four components to it which are as follows:

1. The background of the respondents.

2. The respondents' level of interest in learning al-Qur'an.

3. The respondents' basic knowledge concerning mushtarak elements in al-Qur'an.

4. The respondents' level of comprehension of the translations of the selected five (5) words from al-Qur'an (found in six verses) with mushtarak elements.

For the fourth component of the survey questionnaire, five mushtarak words were selected from six verses in al-Qur'an. The words are 1) al-akhirah (al- Zukhruf: 35) labelled as verse 1, 2) is'au (alJumuah: 9) labelled as verse 2, 3) shahīd (al-Baqarah: 143) labelled as verse 3,4) ummah (Āli Imran: 
104) labelled as verse 4, and 5) imam (Yaasin: 12) labelled as verse 5. For each verse, five questions were listed. Three of the five questions concerned the translation of the word and two other questions concerned the verse.

Selection of respondents was random and structured. The structured selection was made to focus on respondents with strong foundation in education. 300 people were selected as respondents for this study. The respondents comprised individuals between 18 to 60 years old and majority of the respondents were between 20 to 25 years old. $56 \%$ of the respondents were female and $43 \%$ were male. The respondents were members of tertiary institutions and people living in the surrounding area. The data collected were then analysed descriptively using simple percentage calculation.

Apart from the survey, interviews were also conducted in this study. The purpose of the interview is to provide support for data collected from the questionnaire survey. Based on questions from the questionnaire, a set of interview questions was developed. The interview questions were developed accordingly for each verse of al-Qur'an that contains the selected mushtarak words as in the questionnaire. There were two questions for each verse, 1) whether the respondent agrees with the translator's translation of the mushtarak word, and 2) the reason for the respondent's answer for the first question. To help the respondents differentiate between the meanings of the selected words from the Qur'anic verses and the translations of the verse by the translator, literal translations were provided during the interview.

Three respondents were selected for the interviews. The respondents represent three different groups. The first respondent represents the management and professional group, the second respondent was a support staff with diploma to represent the middle group and the third respondent was an upper secondary school student to represent the group without higher education. Out of all three respondents, only the third respondent who was the upper secondary school student came from a background in religious education.

\section{Analysis and Discussion of Findings}

This section of the article which contains discussion on the findings of the study is divided into two parts, 1) background, interest and knowledge of respondents, and 2) data concerning selected alQur'an verses which contain mushtarak elements.

\section{Background, Interests and Knowledge of Respondents}

The respondents comprised nearly equal percentage of individuals with formal and non-formal religious and Arabic education. 49.7\% of the respondents had formal religious and Arabic education and $50.3 \%$ had non-formal religious and Arabic education. However, nearly all the respondents comprising $97.6 \%$ indicated interest to learn more about al-Qur'an.

Only $15.7 \%$ of the respondents are familiar with the term mushtarak, while the rest of the respondents are either uncertain or have never heard of it before. This is because the term mushtarak is common only among those who pursue Arabic and religious studies at higher education. However, when asked about the existence of words that have more than one possible meanings, findings have shown that $76 \%$ of the respondents are aware of it. This is significant as it shows that the concept of words having two or more meanings is a common phenomenon and only the terms used to describe it are different. 
INTERNATIONAL JOURNAL OF ACADEMIC RESEARCH IN BUSINESS AND SOCIAL SCIENCES

Vol. 8, No. 7, July 2018, E-ISSN: 2222-6990 (C) 2018 HRMARS

\section{Respondents' Level of Comprehension}

Verse 1:

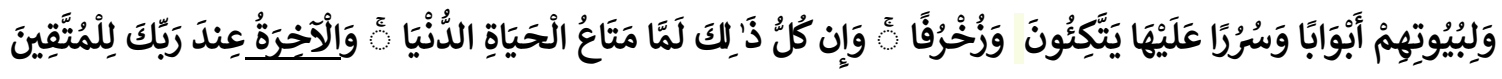
(al-Zukhruf: 34-35)

Dan (ingatlah), segala yang tersebut itu tidak lain hanyalah merupakan kesenangan hidup di dunia; dan (sebaliknya) kesenangan hari akhirat di sisi hukum Tuhanmu adalah khas bagi orang-orang yang bertaqwa (Basmeih 2001).

According to the dictionary, the word al-ākhirah means 1) the last one, and 2) life after death (al-Mucjam al-Wasit 1989). However, al-Munajjid (1999) lists five meanings for this word in al-Qur'an, namely 1) the ending, 2) the Judgment Day, 3) life in the grave or the Barzakh, 5) Paradise, and 6) Hellfire.

The word al-ākhirah in this verse means 'Paradise' (Al-Munajjid, 1999). However, the translator does not directly translate the word as 'Paradise'. Instead, it was translated as 'kesenangan hari akhirat [happiness in the Hereafter]'. The concept of happiness is specifically related to the meaning of 'Paradise'. When 'kesenangan [happiness]' is mentioned with the word 'hari akhirat [the Hereafter]', the target readers will be able to understand that the whole meaning refers to the 'Paradise'. The translator has used the explicitation approach (Vinay \& Darbelnet, 1958/1995) in determining the translation for the word as meant in the verse by adding the word 'kesenangan' before the word 'akhirat', which was translated through borrowing.

Table 1 below shows findings from the questionnaire concerning target text readers' level of comprehension of Verse 35 of Surah al-Zukhruf and the translation for the mushtarak word in the verse:

\begin{tabular}{|c|c|c|c|c|c|c|}
\hline No & Item & $\begin{array}{l}\text { disagre } \\
\text { e }\end{array}$ & $\begin{array}{l}\text { s.disagr } \\
\text { ee }\end{array}$ & $\begin{array}{l}\text { uncerta } \\
\text { in }\end{array}$ & agree & s.agree \\
\hline 1 & Understand the whole verse & $0.3 \%$ & $3.0 \%$ & $12.3 \%$ & $66.7 \%$ & $17.7 \%$ \\
\hline 2 & Translation is easy to understand & $0.7 \%$ & $3.0 \%$ & $10.0 \%$ & $67.7 \%$ & $18.7 \%$ \\
\hline 3 & $\begin{array}{l}\text { Translation of mushtarak word is } \\
\text { appropriate }\end{array}$ & $0 \%$ & $1.7 \%$ & $11.0 \%$ & $66.0 \%$ & $21.3 \%$ \\
\hline 4 & $\begin{array}{l}\text { Translation of mushtarak word is } \\
\text { sufficient }\end{array}$ & $0 \%$ & $2.7 \%$ & $10.7 \%$ & $67.0 \%$ & $19.7 \%$ \\
\hline 5 & $\begin{array}{l}\text { Understand the translation of mushtarak } \\
\text { word }\end{array}$ & $0 \%$ & $2.4 \%$ & $10.3 \%$ & $65.0 \%$ & $22.3 \%$ \\
\hline
\end{tabular}

*s.disagree: slightly disagree; s.agree: strongly agree

Table 1: Findings from the questionnaire on target text readers' level of comprehension of Verse 35 of Surah al-Zukhruf and the translation for the word al-äkhirah 
INTERNATIONAL JOURNAL OF ACADEMIC RESEARCH IN BUSINESS AND SOCIAL SCIENCES Vol. 8, No. 7, July 2018, E-ISSN: 2222-6990 @ 2018 HRMARS

As demonstrated in Table 1, majority of the respondents agree that they can fully understand the translation for Verse 35 of Surah al-Zukhruf with $84.4 \%$ stating they agree and strongly agree. Similarly, $86.4 \%$ of the respondents agree and strongly agree that the translation is easy to understand.

The findings are also similar for questions related to the translation of the word al-äkhirah, which is 'kesenangan hari akhirat'. Most respondents agree that the translation is approriate $(87.3 \%$ agree and strongly agree), sufficient ( $86.7 \%$ agree and strongly agree) and that they understand the translation (87.3\% agree and strongly agree).

However, there are also respondents who are uncertain whether they understand the meaning of the verse as well as the translation for the mushtarak word provided, and they comprise between $10.0 \%$ to $12.3 \%$ out of all respondents for all five questions posed in the questionnaire. In addition, $3.3 \%$ of the respondents do not fully understand the verse and $3.7 \%$ find the translation of the verse difficult to understand. For questions related to the translation of the word al-äkhirah by Abdullah Basmeih in this verse, 1.7\% find the translation unsuitable, $2.7 \%$ find the translation insufficient and $2.4 \%$ do not fully understand the translation.

Meanwhile, findings from the interview have shown that all three respondents agree with the translation 'kesenangan hari akhirat' for the mushtarak word al-äkhirah in this verse. Among the reasons given for their answers is the context of the verse. The word al-äkhirah in the verse refers to something which is beautiful and good, as promised for those who are steadfast in their faith. Thus, the translation 'kesenangan hari akhirat' is suitable for the context of the verse (Suria Hani Ibrahim, interview, 22 July 2014). Furthermore, had the translator merely translated the word al-äkhirah as 'the Hereafter', the translation may confuse readers as 'hari akhirat' has a broad meaning, including Hellfire and torture, whereas, the end of this verse of al-Qur'an specifies steadfast believers (Hidayat Jaafar, interview, 23 July 2014).

\section{Verse 2:}

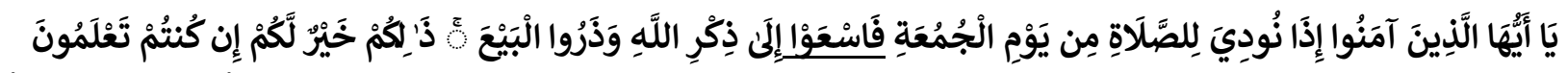
(al-Jumuah: 9)

Wahai orang-orang yang beriman! Apabila diserukan azan (bang) untuk mengerjakan sembahyang pada hari Jumaat, maka segeralah kamu pergi (ke masjid) untuk mengingati Allah (dengan mengerjakan sembahyang jumaat) dan tinggalkanlah berjual-beli (pada saat itu); yang demikian adalah baik bagi kamu, jika kamu mengetahui (hakikat yang sebenarnya) (Basmeih 2001).

The word is $a u$ is the plural form of an imperative word, $s a^{c} a$. The meanings of the word $s a^{c} a$ in the dictionary are 1) to work on something, 2) to go or walk towards a place, 3) to make effort, and 4) to return (al-Mucjam al-Wasit, 1989). In the context of al-Qur'an, al-Munajjid (1999) lists four meanings for $\left.s a^{c} a: 1\right)$ to walk, 2) quick, 3) effort and 4) to be in urgency with determination. For this verse, alMunajjid refers to the fourth meaning of the word is $a u$, which is 'to do something urgently with determination'.

This mushtarak word is translated by Abdullah Basmeih as 'maka segeralah kamu pergi [make haste and go]'. This translation, thus, is similar with the meaning suggested by al-Munajjid. 
INTERNATIONAL JOURNAL OF ACADEMIC RESEARCH IN BUSINESS AND SOCIAL SCIENCES Vol. 8, No. 7, July 2018, E-ISSN: 2222-6990 @ 2018 HRMARS

The survey conducted with the respondents reveals the results as shown in the following Table 3:

\begin{tabular}{|c|c|c|c|c|c|c|}
\hline No & Item & $\begin{array}{l}\text { disagre } \\
\mathrm{e}\end{array}$ & $\begin{array}{l}\text { s.disagr } \\
\text { ee }\end{array}$ & $\begin{array}{l}\text { uncerta } \\
\text { in }\end{array}$ & agree & s.agree \\
\hline 1 & Understand the whole verse & $1.3 \%$ & $1.3 \%$ & $12.0 \%$ & $57.7 \%$ & $27.7 \%$ \\
\hline 2 & Translation is easy to understand & $0.3 \%$ & $2.0 \%$ & $10.3 \%$ & $58.3 \%$ & $29.0 \%$ \\
\hline 3 & $\begin{array}{l}\text { Translation of mushtarak word is } \\
\text { appropriate }\end{array}$ & $0 \%$ & $4.3 \%$ & $14.3 \%$ & $56.0 \%$ & $25.3 \%$ \\
\hline 4 & $\begin{array}{l}\text { Translation of mushtarak word is } \\
\text { sufficient }\end{array}$ & $0 \%$ & $3.3 \%$ & $13.0 \%$ & $60.0 \%$ & $23.7 \%$ \\
\hline 5 & $\begin{array}{l}\text { Understand the translation of mushtarak } \\
\text { word }\end{array}$ & $0.7 \%$ & $3.0 \%$ & $12.3 \%$ & $59.0 \%$ & $25.0 \%$ \\
\hline
\end{tabular}

*s.disagree: slightly disagree; s.agree: strongly agree

Table 3: Findings from frequency analysis on respondents' level of comprehension of Verse 9 of Surah al-Jumu ${ }^{\mathrm{C}}$ ah and the translation for the word is ${ }^{c} a u$

Table 3 shows that most respondents agree with the translator's choice for the word is'au, 'maka segeralah kamu [make haste]'. $85.4 \%$ of the respondents agree and strongly agree that they fully understand the verse and $87.3 \%$ agree that the translation is easy to understand. Meanwhile, for the translation of the word is ${ }^{c} a u, 81.3 \%$ agree that the translation is suitable, $83.7 \%$ agree that the translation is sufficient, and $84 \%$ understand the translation for the word is ${ }^{c} a u$ which is ' $m a k a$ segeralah kamu pergi [make haste and go]'.

However, $10.3 \%$ to $14.3 \%$ of the respondents are uncertain if they understand the meaning of the translation of Verse 9 of Surah al-Jumucah, as well as the translation of the mushtarak word $i s^{c} a u$. Analysis also shows that $2.6 \%$ of the respondents do not fully understand the translation of the verse and $2.3 \%$ think the translation is difficult to understand. As for the translation of the word is ${ }^{c} a u$, 4.3\% think the translation is not wholly suitable, 3.3\% think the translation is insuffeicient and $3.7 \%$ do not understand the meaning of the translation provided for the mushtarak word.

Overall, analysis of findings from the questionnaire has shown that majority of the respondents agree with the translation by Syeikh Abdullah Muhammad Basmeih. The findings are also supported by findings from the interviews with the three selected respondents. All three respondents agree with the translation provided. They mostly believe the translation is very appropriate and easy to understand (Hidayat Jaafar, interview, 23 July 2014 \& Suria Hani Ibrahim, interview, 22 July 2014). Karimi Muda (interview, 22 July 2014) meanwhile thinks the translation produced by the translator is easier to understand for readers who do not have the skills for comprehending Arabic.

Verse 3:

(Al-Baqarah: 143)

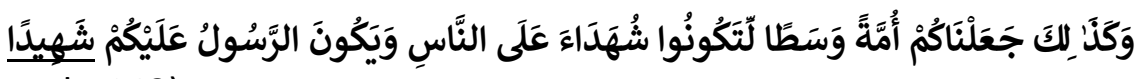

Dan demikianlah (sebagaimana Kami telah memimpin kamu ke jalan yang lurus), Kami jadikan kamu (wahai umat Muhammad) satu umat yang pilihan lagi adil, supaya kamu layak menjadi orang yang memberi keterangan kepada umat manusia (tentang yang benar dan yang salah) dan Rasulullah 
INTERNATIONAL JOURNAL OF ACADEMIC RESEARCH IN BUSINESS AND SOCIAL SCIENCES

Vol. 8, No. 7, July 2018, E-ISSN: 2222-6990 @ 2018 HRMARS

(Muhammad) pula akan menjadi orang yang menerangkan kebenaran perbuatan kamu. (Basmeih 2001)

The dictionary definitions for the word shahidan are 1) someone who is killed in the path of Allah, and 2) witness (al-Mucjam al-Wasit 1989). According to al-Munajjid (1999), in the context of alQur'an, the word shahid has eight meanings which are 1) prophet, 2) messenger, 3) a ruler who protects, 4) the people of Muhammad s.a.w, 5) messenger of the truth, 6) individuals who die in the path of Allah s.w.t, 7) individuals who are present and 8) partner (idol).

The translation given by the translator for the word shahidan in this verse agrees with the fifth meaning suggested by al-Munajjid, which is 'penerang kebenaran [messenger of the truth]'. However, the translation is made more detailed into 'orang yang menerangkan kebenaran [the one who explains the truth]'.

Analysis of data from the questionnaire shows the following findings:

\begin{tabular}{|c|c|c|c|c|c|c|}
\hline No & Item & $\begin{array}{l}\text { disagre } \\
\mathrm{e}\end{array}$ & $\begin{array}{l}\text { s.disagr } \\
\text { ee }\end{array}$ & $\begin{array}{l}\text { uncerta } \\
\text { in }\end{array}$ & agree & s.agree \\
\hline 1 & Understand the whole verse & $1.0 \%$ & $7.7 \%$ & $18.7 \%$ & $57.3 \%$ & $15.3 \%$ \\
\hline 2 & Translation is easy to understand & $0.7 \%$ & $8.0 \%$ & $18.3 \%$ & $59.3 \%$ & $13.7 \%$ \\
\hline 3 & $\begin{array}{l}\text { Translation of mushtarak word is } \\
\text { appropriate }\end{array}$ & $1.3 \%$ & $8.7 \%$ & $26.0 \%$ & $50.0 \%$ & $14.0 \%$ \\
\hline 4 & $\begin{array}{l}\text { Translation of mushtarak word is } \\
\text { sufficient }\end{array}$ & $0.7 \%$ & $9.3 \%$ & $19.3 \%$ & $58.7 \%$ & $12.0 \%$ \\
\hline 5 & $\begin{array}{l}\text { Understand the translation of mushtarak } \\
\text { word }\end{array}$ & $2.0 \%$ & $8.0 \%$ & $18.3 \%$ & $55.3 \%$ & $16.3 \%$ \\
\hline
\end{tabular}

*s.disagree: slightly disagree; s.agree: strongly agree

Table 4: Findings from frequency analysis on respondents' level of comprehension of Verse 143 of Surah al-Baqarah and the translation for the word shahid

Table 4 shows that $72.6 \%$ of the respondents agree and strongly agree that they fully understand the translation of the verse and $73 \%$ agree and strongly agree that the language used by translator in translating the verse is easy to understand. As for the translation of the word shahidan into 'orang yang menerangkan kebenaran', 64\% agree and strongly agree that the translation is appropriate, $70.7 \%$ think the translation is sufficient and $71.6 \%$ of the respondents understand the translation of the word.

However, the analysis also shows that there are between $18.3 \%$ to $26.0 \%$ of respondents who are uncertain if they agree or disagree with the translation of Verse 143 of Surah al-Baqarah and the translation of the word shahidan. As for the rest of the respondents, $8.7 \%$ could not understand the translation of the verse and $8.7 \%$ also think that the language used in the translated verse is difficult to understand. Meanwhile, for the translation of the mushtarak word, $10 \%$ of the respondents think the translation given is unsuitable, insufficient and incomprehensible.

Findings from the interviews with the three selected respondents show that only one respondent agrees with the translation by the translator with the reason that the translation is suitable to describe the task of the Messenger as someone who guides towards the right path 
INTERNATIONAL JOURNAL OF ACADEMIC RESEARCH IN BUSINESS AND SOCIAL SCIENCES

Vol. 8, No. 7, July 2018, E-ISSN: 2222-6990 @ 2018 HRMARS

(Hidayat Jaafar, interview, 2014). However, two of the respondents do not agree with the translation 'orang yang menerangkan kebenaran' in this verse with the reason that the translation is vague and confusing. In their opinion, the literal translation 'saksi [witness]' is clearer and more appropriate for the translated verse (Karimi Muda, interview, 22 July 2014 \& Suria Hani Ibrahim, interview, 22 July 2014).

Verse 4:

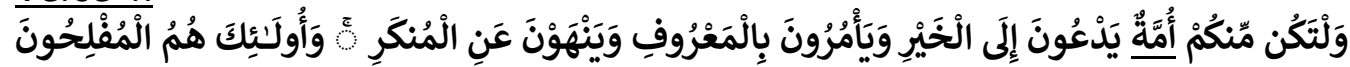

(Ali-Imran: 104)

Dan hendaklah ada di antara kamu satu puak yang menyeru (berdakwah) kepada kebajikan (mengembangkan Islam), dan menyuruh berbuat segala perkara yang baik, serta melarang daripada segala yang salah (buruk dan keji). Dan mereka yang bersifat demikian ialah orang-orang yang berjaya (Basmeih 2001).

The dictionary definitions for the word ummah are 1) mother, 2) a group of people from the same origin, or with the same purpose or belief, 3) generation, 4) religion, and 5) method or path (alMucjam al-Wasit, 1989). Meanwhile, according to al-Munajjid (1999), this word has eight meanings in the context of al-Qur'an which are 1) group, 2) religion, 3) certain times or periods, 4) race or tribe, 5) imam, 6) the previous people, 8) the people of Muhammad s.a.w who are believers and 8) the people of Muhammad s.a.w who are disbelievers.

In Tafsir Pimpinan Ar-Rahman Kepada Pengertian Al-Qur'an, the translation given is 'satu puak [a tribe]'. According to Kamus Dewan (1997), the word 'puak' refers to 'kelompok, golongan atau kumpulan [faction, sect or group]'.

Analysis from the questionnaire shows the following findings:

\begin{tabular}{|l|l|l|l|l|l|l|}
\hline No & Item & $\begin{array}{l}\text { disagre } \\
\mathrm{e}\end{array}$ & $\begin{array}{l}\text { s.disagre } \\
\mathrm{e}\end{array}$ & $\begin{array}{l}\text { uncerta } \\
\text { in }\end{array}$ & agree & s.agree \\
\hline 1 & Understand the whole verse & $0.7 \%$ & $2.3 \%$ & $10.7 \%$ & $62.3 \%$ & $24 \%$ \\
\hline 2 & Translation is easy to understand & $0 \%$ & $2 \%$ & $9.7 \%$ & $65.3 \%$ & $23 \%$ \\
\hline 3 & $\begin{array}{l}\text { Translation of mushtarak word is } \\
\text { appropriate }\end{array}$ & $0.3 \%$ & $3.3 \%$ & $15.3 \%$ & $59 \%$ & $22 \%$ \\
\hline 4 & $\begin{array}{l}\text { Translation of mushtarak word is } \\
\text { sufficient }\end{array}$ & $0.3 \%$ & $3.7 \%$ & $13 \%$ & $61 \%$ & $22 \%$ \\
\hline 5 & $\begin{array}{l}\text { Understand the translation of mushtarak } \\
\text { word }\end{array}$ & $0.3 \%$ & $1.7 \%$ & $12.7 \%$ & $61.3 \%$ & $24 \%$ \\
\hline
\end{tabular}

*s.disagree: slightly disagree; s.agree: strongly agree

Table 5: Findings from frequency analysis on respondents' level of comprehension of Verse 104 of Surah Ali Imran and the translation for the word ummah

Table 5 shows that $86.3 \%$ of the respondents understand the translation of the verse containing the selected mushtarak word. $88.3 \%$ agree and strongly agree that the language used in the translation of the verse is easy to understand. As for the translation of the word ummah which is 'satu puak', $81 \%$ of the respondents think the translation is appropriate, $83 \%$ agree that the translation is 
INTERNATIONAL JOURNAL OF ACADEMIC RESEARCH IN BUSINESS AND SOCIAL SCIENCES

Vol. 8, No. 7, July 2018, E-ISSN: 2222-6990 @ 2018 HRMARS

sufficient to understand and $85.3 \%$ understand the meaning of the translated word in the context of the verse.

The results of the analysis, however, also find that between $9.7 \%$ to $15.3 \%$ of the respondents are uncertain if they agree or disagree with the translation. Furthermore, $3 \%$ of the respondents do not fully understand the verse, $2 \%$ find it difficult to understand the language used, $3.6 \%$ think the translation for the word ummah is unsuitable, $4 \%$ think the translation of the word is insufficient and $2 \%$ do not understand the meaning of the word.

Analysis of data from the interview on the translation of the verse as well as the translation for the mushtarak word shows only one of the respondents agrees with the translation in Tafsir Pimpinan Ar-Rahman Kepada Pengertian Al-Qur'an. The reason given for their answer is that the translation 'satu puak' is clear and specific to show that there is a need for there to be one group among the Muslims who call towards righteousness. However, the other two respondents from the interviews do not agree with the translation for the word ummah because the word 'puak' has a relatively harsh connotation and is too general to refer to the Muslims. The respondents believe the word ' umat', which is a Malay word that is borrowed from Arabic and is widely accepted and used in the Malay language, is a better choice to translate the mushtarak word.

$\underline{\text { Verse 5: }}$

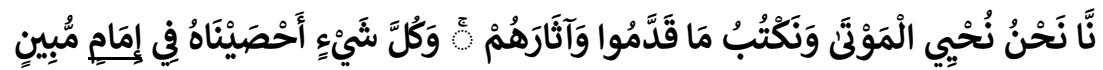

(Yaasin: 12)

Sesungguhnya Kami menghidupkan orang-orang yang mati, dan Kami tuliskan segala yang mereka telah kerjakan serta segala kesan perkataan dan perbuatan yang mereka tinggalkan. Dan (ingatlah) tiap-tiap sesuatu kami catitkan satu persatu dalam Kitab (ibu Suratan) yang jelas nyata (Basmeih 2001).

The dictionary definitions for the word imam are 1) leader, 2) imam (in prayer), 3) war chief, and 4) signs for the explorers (al-Mucjam al-Wasit 1989: 27). al-Munajjid (1999) on the other hand, states that there are five (5) meanings in al-Qur'an for the word imam which are 1) leader, 2) books of deeds, 3) luh mahfuz, 4) the Taurat book, and 5) a bright path.

The translation of the word imam in this verse does not echo any of the definition listed in the dictionary or by al-Munajjid. Instead, the word is translated as 'kitab [book]' and is further explained using the explicitation method as 'ibu suratan [mother of scripts]' in brackets. This choice of translation is found difficult to understand as the combination of the terms 'kitab [book]' and 'ibu suratan [mother of scripts]' is not commonly found in the Malay language. 
INTERNATIONAL JOURNAL OF ACADEMIC RESEARCH IN BUSINESS AND SOCIAL SCIENCES Vol. 8, No. 7, July 2018, E-ISSN: 2222-6990 @ 2018 HRMARS

Analysis of data from the questionnaire shows the following findings:

\begin{tabular}{|l|l|l|l|l|l|l|}
\hline No & Item & $\begin{array}{l}\text { disagre } \\
\text { e }\end{array}$ & $\begin{array}{l}\text { s.disagr } \\
\text { ee }\end{array}$ & $\begin{array}{l}\text { uncerta } \\
\text { in }\end{array}$ & agree & s.agree \\
\hline 1 & Understand the whole verse & $2 \%$ & $9 \%$ & $32 \%$ & $45 \%$ & $12 \%$ \\
\hline 2 & Translation is easy to understand & $0.7 \%$ & $17 \%$ & $17.7 \%$ & $56.6 \%$ & $8 \%$ \\
\hline 3 & $\begin{array}{l}\text { Translation of mushtarak word is } \\
\text { appropriate }\end{array}$ & $\begin{array}{l}\text { Translation of mushtarak word is } \\
\text { comprehensible }\end{array}$ & $10.3 \%$ & $34.7 \%$ & $42.7 \%$ & $8.7 \%$ \\
\hline 5 & $\begin{array}{l}\text { Understand the translation of mushtarak } \\
\text { word }\end{array}$ & $2.0 \%$ & $10.7 \%$ & $24 \%$ & $50.7 \%$ & $12.7 \%$ \\
\hline
\end{tabular}

*s.disagree: slightly disagree; s.agree: strongly agree

Table 6: Findings from frequency analysis on respondents' level of comprehension of Verse 12 of Yaasin and the translation for the word imam

Table 6 shows that $57 \%$ of the respondents fully understand the verse containing the mushtarak word, imam. $64.6 \%$ think the language used in the translation of the verse is easy to understand. $51.4 \%$ of the respondents agree that the translation of the mushtarak word is suitable. $52.6 \%$ believe that the translation is sufficient and $63.4 \%$ of the respondents understand the meaning of the translation. However, the analysis results also show a relatively high percentage of respondents who are uncertain, which is between $17.7 \%$ to $34.7 \%$. In addition, $11 \%$ of the respondents do not understand the translation of the verse, $17.7 \%$ of the respondents think the language in the translation of the verse is difficult to understand, $13.5 \%$ do not agree with the translation of the mushtarak word, $21 \%$ think the translation of the word is insufficient to allow full comprehension of the verse and $12.7 \%$ do not understand the translation.

On the other hand, two of the respondents from the interview agree with the translation. The two respondents believe that by translating imam as 'Kitab (ibu Suratan) [Book (mother of scripts)]', the translator has made it easy for the meaning of the translated verse to be understood (Hidayat Jaafar, interview, 23 July 2014). However, one of the respondents does not agree with the translation, citing that the translation is slightly awkward in the Malay language (Karimi Muda, interview, 22 July 2014).

The overall findings from the questionnaire for all six selected mushtarak words and al-Qur'an verses are as follows:

\begin{tabular}{|l|l|l|l|l|}
\hline Item & Mushtarak & S.Agree/Agree [\%] & Uncertain [\%] & $\begin{array}{l}\text { S.Disagree/Disagr } \\
\text { ee [\%] }\end{array}$ \\
\hline 1 & al-akhirah [al-Zukhruf: 35] & $84.4-87.3$ & $10-12.3$ & $1.7-3.7$ \\
\hline 2 & al-akhirah [al-Zumar: 9] & $81-88.3$ & $8.3-14.7$ & $1.7-4.4$ \\
\hline 3 & iscau [al-Jumuah: 9] & $81.3-87.3$ & $10.3-14.3$ & $2.3-4.3$ \\
\hline 4 & shahídan [Al-Baqarah:143] & $64-73$ & $18.3-26$ & $8.7-10$ \\
\hline 5 & ummah [Ali-Imran: 104] & $81-88.3$ & $9.7-15.3$ & $2-4$ \\
\hline 6 & imam [Yaasin :12] & $51.4-64.6$ & $17.7-34.7$ & $11-21$ \\
\hline
\end{tabular}

*s.disagree: slightly disagree; s.agree: strongly agree

Table 7: The overall findings from the questionnaire survey 
INTERNATIONAL JOURNAL OF ACADEMIC RESEARCH IN BUSINESS AND SOCIAL SCIENCES Vol. 8, No. 7, July 2018, E-ISSN: 2222-6990 @ 2018 HRMARS

The overall findings shown in Table 7 have demonstrated that majority of the respondents agree with Abdullah Basmeih's translations of the mushtarak words and the verses in Tafsir Pimpinan ArRahman Kepada Pengertian Al-Qur'an. This is most likely the result of the translator's great effort to apply a translation approach that could help readers understand the content from the source text. The results of the analysis indicated that the translator has attempted to apply the explicitation approach in his translation. To translate the word al-äkhirah in Verse 35 of Surah al-Zukhruf, for example, the translator has employed the 'explicitation in the text' approach by adding the word 'kesenangan [happiness]'. Similarly, the word imam in Verse 12 of Surah Yaasin is translated as 'kitab (ibu suratan) [book (mother of scripts)], which employs the use of explicitation in brackets. Thus, Abdul-Raof's suggestion (2001) for translators to use explanation or the explicitation approach is proven to be effective in helping readers understand the translation of al-Quran.

In addition, findings also show that respondents' positive reactions are also influenced in part by the context of the verse. Apart from the explicitation approach, context also plays an important role in determining the suitable translation, as seen in the translation of Verse 9 of Surah al-Jumuah which contains the mushtarak word is'au. The context of the verse which tells of the command to hurry and make way to the mosque for Friday prayers can help readers' comprehension of the translation 'maka bersegeralah pergi [make haste and go]' for the source word is'au. In cases such as this, Lyons (1981) says that the words become disambiguous when put in a sentence or context.

As for the translation of the mushtarak word 'shahidan' in Verse 143 of Surah al-Baqarah, the percentage of respondents who agree with the translation has gone down, which is in part due to the vague context because only one verse of the surah was shown to them. According to Al-Zamakhsyari $(1995 / 1)$, this verse has an extensive background explanation in the verses before and after it.

Readers of translated texts also face difficulties to understand the text if the translations given are awkward in the target language. For example, the mushtarak word 'imam' in Verse 104 of Surah Ali Imran is translated as 'Kitab (ibu Suratan) [Book (mother of Scripts)]'. The meaning of the word ' $k i t a b$ ' which is borrowed from Arabic has been narrowed down in the Malay language and is only used to refer to religious books. As this verse is related to the books of good and bad deeds of every person, the translation ' $k i t a b$ ' which only refers to religious books in Malay has confused the readers of the Qur'an translation because the meaning understood by the target readers is 'human's deeds are written in religious books'. Furthermore, the phrase 'ibu suratan', which is the element of explicitation in this verse, is an awkward phrase in Malay. Due to these reasons, several respondents do not agree with, and a few others are uncertain of the translator's choice of the words as well as the overall meaning of the verse. Such is also the case for the mushtarak word 'shahidan' in verse 143 of Surah al-Baqarah, whereby the translation is thought to be vague and confusing.

The translator is also inclined to use general words in his translation. This in turn causes difficulties for readers to understand the meaning of verses which contain mushtarak words. For instance, the word 'ummah' in Verse 104 of Surah Ali Imran is translated as 'satu puak [a tribe]'. The word 'tribe' has a more general meaning and a harsh connotation in the Malay language compared to 'umat' which is more suitable for referring to the Muslims.

Findings from the analysis also show that several respondents have chosen to take a neutral stance by giving uncertain answers in the questionnaire. This is due in part to the nature of al-Quran as a sensitive text. Religious texts are considered as sensitive. Thus, many respondents are afraid to comment on the translation. This finding is supported by the initial reactions of the three interview respondents who voiced their doubts as the questions are related to the translation of al-Qur'an. 
INTERNATIONAL JOURNAL OF ACADEMIC RESEARCH IN BUSINESS AND SOCIAL SCIENCES

Vol. 8, No. 7, July 2018, E-ISSN: 2222-6990 @ 2018 HRMARS

\section{Conclusion}

This study is carried out to evaluate the readers' comprehension of the translation of mushtarak words and the related verses in the Malay translation of al-Qur'an by Abdullah Basmeih, titled Tafsir Pimpinan Ar-Rahman Kepada Pengertian Al-Qur'an. For the purpose of this study, 300 respondents were selected as questionnaire respondents and three respondents were selected for interviews. Five mushtarak words in five verses were selected. The words are 1) al-äkhirah (al- Zukhruf: 35), 2) is'au (al-Jumuah: 9), 3) shahīd (al-Baqarah: 143, 4) ummah (Āli Imran: 104), and 5) imam (Yaasin: 12). Findings from the study have shown that most of the readers understand Abdullah Basmeih's translation of the mushtarak words. They also understand the overall meaning of the verses which contain these words. This means that Abdullah Basmeih's translation is effective in helping readers of the Malay translation understand the meaning of al-Quran. It is evident that the translator has put a great effort in finding suitable translations to deliver the true meaning of the words or verses of the source text. The translator's effort to help readers of al-Qur'an translation understand the text can be seen through his use of explanation, which is better known as the explicitation approach in translation. However, revisions and improvements are needed as parts of this translation are thought to be quite confusing for the readers. This includes selections of equivalents that are vague or awkward in the target language, are too general or not reflecting the original connotations in the source language.

\section{Acknowledgement}

This work was supported in part by Bridging Grant of Universiti Sains Malaysia under Grant No: 304/PHUMANITI/6316197. Title of the project is 'The Translation of Qur'an into Malay: A Study towards the Development of a Systematic Assessment Guideline of the Translation of the Qur'an.

\section{Corresponding Author}

Idris Mansor

Senior Lecturer, School of Humanities, Universiti Sains Malaysia, 11800 USM Pulau Pinang, Malaysia. Email: idrismansor@usm.my

\section{References}

Abdul-Raof, H. (2001). Qur'an Translation: Discourse, Texture and Exegesis. Surrey: Curzon Press. Al-Mucjam al-Wasit. (1989). Istanbul: Dar Ad-Dacwah.

Al-Munajjid, M. N. (1999). Al-Ishtirāk al-Lafdhi fï al-Qurān al-Karīm Bayn an-Nadhariyyah wa alTațbiq. Damascus: Dar Fikr.

Al-Zamakhsyari, M. (1995). Tafsīr Al Kasshāf. Beirut: Dar Al Kutub Al-Ilmiah.

Basmeih, A. (1970). Tafsir Pimpinan Ar-Rahman Kepada Pengertian Al-Qur'an. Kuala Lumpur: Jabatan Kemajuan Islam Malaysia.

Dastjerdi, H. V., \& Zamani, B. (2009). A Semantic Study of the Translation of Homonymous Terms in Sacred Texts: The Qur'an in Focus. Journal of Language \& Translation, 10(1), $45-79$.

Fadzil, A. (2007). Anatomi al-Quran: Mengenal Ilmu, Sejarah dan Kandungan al-Quran. Selangor, Malaysia: PTS Islamika.

Hanapi, M. S. (2013). Terjemahan Al-Qur'an Dalam Pelbagai Perspektif. Kuala Lumpur: Utusan Publications \& Distributors.

Hudson, G. (2000). Essential Introductory Linguistics. Massachusetts, USA: Blackwell Publishers Inc. Ibn Faris, A. (1997). Al-Șāḥibī Fi Fiqh Al-Lughah. Beirut: Dar Al-Kutub Al-IImiah. 
INTERNATIONAL JOURNAL OF ACADEMIC RESEARCH IN BUSINESS AND SOCIAL SCIENCES

Vol. 8, No. 7, July 2018, E-ISSN: 2222-6990 @ 2018 HRMARS

Idris, M. (2012). 'Acceptability' in the Translation into Malay of Rihlat Ibn Battuta. Kemanusiaan: The Asian Journal of Humanities, 19(2), 1-18.

Dewan, K. (3 ${ }^{\text {rd }}$ ed.). (1997). Kuala Lumpur: Dewan Bahasa dan Pustaka.

Larson, M. (1984). Meaning-Based Translation: A Guide to Cross-Language Equivalence. Lanham, New York \& London: University Press of America.

Lyons, J. (1981). Language, Meaning and Context. Suffolk: Fontana Paperbacks.

Newmark, P. (1998). Approaches to Translation. New York, London, Toronto, Sydney, Tokyo \& Singapore: Prentice Hall.

Shuttleworth, M., \& Cowie, M. (1997). Dictionary of Translation Studies. Manchester: St. Jerome.

Vinay, J. P., \& Darbelnet, J. (1995). Comparative Stylistics of French and English: A Methodology for Translation. Amsterdam \& Philadelphia: John Benjamins. 